\title{
PENGENALAN WEBSITE SEKOLAH DASAR MUHAMMMADIYAH 1 UNGGULAN DALAM RANGKA MENINGKATKAN MUTU PEMBELAJARAN DAN PROMOSI SEKOLAH
}

\author{
Muhammad Imanullah $^{1)^{*}}$, Onsardi ${ }^{2)}$, Rozali Toyib ${ }^{3)}$, Mehadi Tri Hidayat ${ }^{4)}$ \\ Irvan Wahyudi' ${ }^{5)}$, Ageng Abimanyu' ${ }^{6}$, Afensyah Bartha Susanto ${ }^{7)}$ \\ ${ }^{134567)}$ Program Studi Teknik Informatika, Fakultas Teknik, Universitas Muhammadiyah Bengkulu \\ ${ }^{2)}$ Program Studi Manajemen, Fakultas Ekonomi, Universitas Muhammadiyah Bengkulu \\ *Corresponding author: rozalitoyib@umb.ac.id
}

\section{Informasi Artikel \\ Terima: $14 / 12 / 2020$ \\ Revisi : 01/04/2021 \\ Disetujui : 27/04/2021}

Kata Kunci: sekolah, website, media sosial, promosi, video

\section{ABSTRAK}

Visi dan misi Sekoalah SD Muhammadiyah 1 Unggulan Kota Bengkulu ini menjadi acuan dalam rangka mengembangkan sekolah ini menjadi sekolah yang dapat diperhitung secara lokal maupun nasional untuk itu dibutuhkan media informasi yang memungkinkan semua kegiatan dapat disosialisasi lebih luas dan bisa menjadi sarana peningkatan belajar mengajar serta menjadi media promosi bagi institusi, hal ini menjadi kendala selama ini sehingga perlu dibangun sebuah website sekolah dalam meningkatkan mutu pembelajaran dan promosi sekolah. Website adalah situs yang dapat diakses dan dilihat oleh para pengguna internet, pengguna internet semakin hari semakin bertambah banyak, sehingga hal ini adalah potensi pasar yang berkembang terus, perilaku pengguna internet yang mengakses melalui perangkat mobile atau smartphone sehingga data dapat diakses dan dilihat oleh orang semua orang untuk memperkenalkan sekolah lebih luas lagi tidak hanya skala lokal tetapi nasional juga. Berdasarkan pengabdian masyarakat yang telah dilakukan dapat diabil kesimpulan Dari hasil Kuisoner yang diberikan untuk penggunaan media website yang terhubung dengan sosial media seperti Face Book, Twitter, Istagram dan Telegram dengan rank 81\%-90\% sebagai sarana promosi kegiatan dan prestasi guru/staf, siswa dan masyarakat umum, promosi sekoah mengenai kegiatankegiatan yang dilakukan dan prestasi-prestasi yang dicapai baik oleh guru maupun siswanya untuk memperkenal sekolah lebih baik lagi, perlu dilakukan pengembangan lebih lanjut dari website dengan selalu mengupdate kegiatan dan dikembangkan lebih lanjut dengan sosial media dengan mengupload videovideo kegiatan dengan tema-tema yang menarik, peningkatan sumber daya manusia khususnya guru dengan mengenalkan teknologi yang terbaru yang bisa digunakan dalam pengembangan diri.

\section{PENDAHULUAN}

SD Muhammadiyah 1 Kota Bengkulu merupakan salah satu amal usaha Muhammadiyah dan merupakan SD Labor Universitas Muhammadiyah Bengkulu dibawah Pimpinan Cabang 
Muhammadiyah 01 . berdiri pada tahun 1926 dan terus melakukan perbaikan serta peningkatan mutu, yang mempunyai vissi dan misi sekolah yaitu Visi: Mewujudkan SD Muhammadiyah 1 Kota Bengkulu sebagai Taman Pendidikan yang menyenangkan dan unggul dalam mewujudkan generansi Qur'ani, berkarakter, Cerdas, Berprestasi menuju insan Berwawasan Global dan Misi: Melaksanakan pembelajaran dan bimbingan secara efektif sehingga potensi siswa dapat berkembang secara optimal, mengembangkan pembelajaran yang memberikan kesempatan untuk mengembangkan aspek koknitif, afektif dan psikomotor guna pembentukan insan pemecah masalah, embangkitkan budaya disiplin dan etos kerja yang tinggi, membentuk lingkungan pendidikan disekolah yang mampu menumbuhkan dan meningkatkan kualitas keagamaan siswa, membangkitkan semangat berperestasi seluruh warga sekolah, menumbuhkan kesadaran dan kepedulian terhadap lingkungan, menumbuhkan manajemen parsitipatif yang melibatkan siswa, guru, Orang tua dan Stakeholder Sekolah. Visi dan misi ini menjadi acuan dalam rangka mengembangkan sekolah ini menjadi sekolah yang dapat diperhitung secara lokal maupun nasional untuk itu dibutuhkan media informasi yang memungkinkan semua kegiatan dapat disosialisasi lebih luas dan bisa menjadi sarana peningkatan belajar mengajar serta menjadi media promosi bagi institusi, hal ini menjadi kendala selama ini sehingga perlu dibangun sebuah website sekolah dalam meningkatkan mutu pembelajaran dan promosi sekolah.

Website disebut juga site, situs, situs web atau portal merupakan kumpulan halaman web yang berhubungan antara satu dengan lainnya, halaman pertama sebuah website adalah home page, sedangkan halaman demi halamannya secara mandiri disebut web page, dengan kata lain website adalah situs yang dapat diakses dan dilihat oleh para pengguna internet diseluruh dunia. Website adalah situs yang dapat diakses dan dilihat oleh para pengguna Internet, pengguna internet semakin hari semakin bertambah banyak, sehingga hal ini adalah potensi pasar yang berkembang terus, perilaku pengguna internet yang mengakses melalui perangkat mobile atau smartphone di Indonesia sebanyak 94\% menggunakan smartphone untuk mencari informasi lokal tentang daerah, pengguna smartphone sebesar95\% menggunakan smartphone untuk mencari informasi tentang produk-produk yang ada dan sebanyak $57 \%$ menggunakan smartphone untuk melakukan pembelian produk secara online, Web Server adalah tempat anda mendapatkan halaman web dan data yang berhubungan dengan website yang anda buat, sehingga data dapat diakses dan dilihat oleh orang lain (Abas 2013)-(Haekal and Widjajanta 2016)-((Budi Sutedjo 2007).

Media pembelajaran berasal dari bahasa latin "medius" yang secara harfiah berarti "tengah", perantara atau pengantar (Ekayani 2017). Dalam bahasa Arab, media perantara atau pengantar pesan dari pengirim kepada penerima pesan, Pembelajaran adalah sebuah proses interaksi edukatif antara peserta didik, guru dan lingkungan yang melibatkan berbagai komponen pembelajaran untuk mencapai tujuan pembelajaran yang telah direncanaka (Wahidin 2018). Pemanfaatan media dalam pengajaran seharusnya merupakan bagian yang harus mendapat perhatian dari guru sebagai fasilitator dalam setiap kegiatan pembelajaran. Oleh karena itu setiap pendidik perlu mempelajari bagaimana memilih dan menetapkan media pembelajaran agar pencapaian tujuan pembelajaran dalam proses belajar mengajar dengan optimal(Tafonao 2018). 
Media sosial adalah media yang memawadai kerjasama dianatara pengguna yang menghasilkan konten (user generation content), Pencarian informasi dan kemudahan pengunaan media sosial merupakan tahap terpenting untuk pengambilan keputusan dalam berbelanja di media sosial. Sebelum konsumen melakukan pembelian, biasanya mereka akan mencari informasi mengenai produk yang diinginkan ataupun produk yang sedang ditawarkan oleh produsen, Media sosial mampu mengubah pola distiribusi informasi karena memungkinkan seseorang melakukan percakapan tanpa dihambat oleh ruang. Sifat unik media sosial mempunyai potensi untuk mengubah cara manusia berinteraksi. Hanya saja membutuhkan waktu untuk membuat seseorang terpuaskan dengan menggunakan media sosial (Ratnamulyani and Maksudi 2018)(Setiawati 2015)-(Arianti 2017).

Strategi promosi secara digital ini lebih prospektif karena memungkinkan para calon pelanggan potensial untuk memperoleh segala macam informasi mengenai produk dan bertransaksi melalui internet. Internet adalah singkatan dari Interconection Network yang secara sederhana diartikan sebagai global networking of computer networks(Toyib et al. 2020). Promosi ada hakekatnya adalah suatu bentuk komunikasi pemasaran yang bertujuan mendorong permintaan. Yang dimaksud komunikasi pemasaran adalah aktivitas pemasaran yang berusaha menyebarkan informasi, mempengaruhi dan atau mengingatkan pasar sasaran atas perusahaan dan produknya agar bersedia menerima, membeli, dan loyal pada produk atau jasa yang ditawarkan perusahaan yang bersangkutan(Toyib et al. 2020).

Teknologi komputer tidak lagi hanya digunakansebagai sarana komputasi dan pengolahan data tetapi juga sebagai sarana belajar untuk mendesain dan merekayasa suatu konsep dan ilmu pengetahuan. Komputer dengan kemampuan yang dapat mengkombinasikan berbagai unsur penyampaian informasi dan pesan, dapat dirancang dan digunakan sebagai media teknologi yang efektif untuk mempelajari dan mengajarkan materi pembelajaran yang relevan(Jayawardana 2017).

Sikap yang dapat diambil dalam rangka peningkatan mutu sekolah dalam menghadapi era teknologi informasi. Ada empat solusi yang ditawarkan pada pengabdian kali ini yaitu sebagai berikut:

1. Sistem Informasi dengan menggunakan website

Perkembangan dan pertumbuhan teknologi informasi yang sangat pesat memberikan dampak positif bagi perusahaan yang bergerak dalam bidang industri, penjualan dan jasa. Keberadaan teknologi informasi membawa perubahan yang cukup signifikan terjadinya proses transformasi bisnis kearah digitisasi, mobilitas modal dan liberalisasi, Website atau situs dapat diartikan sebagai kumpulan halaman halaman yang digunakan untuk menampilkan informasi, teks, gambar diam atau bergerak, animasi, suara, dan atau gabungan dari semuanya itu, baik yang bersifat statis maupun dinamis yang membentuk satu rangkaian bangunan yang saling berkaitan dimana masing masing dihubungkan dengan jaringan jaringan halaman (hyperlink), Sistem informasi dapat dikatakan sebagai sebuah kegiatan pengolahan data yang dimulai dari mengumpulkan, memperoses, menganalisis, menyimpan, danmenyebarkan suatu infomasi demi untuk kemanjuan atau kepentingan suatu organisasi. 
(Utama 2011)- (Meyliana 2014)(Wardani 2013).

2. Peningkatan Mutu Pembelajaran dengan Media Digital

Model pembelajaran era ditigal saat ini memiliki perbedaan dibandingkandengan model pembelajaran konvensional. Menurut penulis bahwa model pembelajaran era digital terdiri 3 model: pertama, guru / dosen memberikan materi pembelajaran secara online pada peserta didik kemudian di donload dan dipelajari secara manual (ofline), kedua, guru/ dosen memberikan materi pembelajaran secara online dan peserta didik mempelajari secara online juga, dan ketiga, kolaborasi antara pembelajaran yang berlangsung antara online dengan offline. Kemudian ada juga model pembelajaran yang tidak terikat dengan guru/ dosen yang memberikan materi pembelajaran tetapi dapat mengakses informasi pembelajaran secra personal dengan sumber-sumber pembelajaran secara online. Apalagi saat ini era digital yang didukung jaringan internet sangat memungkinkan setiap orang dapat belajar sendiri tanpa diarahkan oleh guru/ dosen secara real(Azis 2019). Proses pembelajaran terdapat beberapa komponen. Dua diantaranya adalah guru sebagai pendidik dan siswa sebagai peserta didik. Agar proses pembelajaran berhasil, guru harus mempunyai inisiatif dan langkahlangkah yang tepat dalam hal mendorong siswa untuk aktif belajar serta memberikan pengalaman belajar yang memadai kepada siswa. Pada saat pembelajaran berlangsung, terdapat suatu proses komunikasi antara guru dengan siswa. Oleh karena itu dalam proses pembelajaran diperlukan suatu media pembelajaran agar dapat menciptakan komunikasi yang baik, Revolusi industri 4.0 membawa pengaruh besar terhadap perubahan disemua sektor kehidupan. Dalam dunia pendidikan revolusi industri ini membawa pengaruh terhadap perilaku interaksi antara guru dan siswa mengalamI perubahan. Dimana semula berbasis tatap muka dikelas, berubah dengan berkolaborasi dengan memanfaatkan jaringan internet (Online Learning)(Kaiful 2013)-(Putri and Muzakki 2019).

3. Promosi lewat Media sosial

Penggunaan media sosial digunakan oleh masyarakat dalam melakukan banyak aktivitas mulai dari entertainment, melakukan bisnis, mencari info atau aktivitas lainnya. Pengguna internet aktif di Indonesia per Januari 2016 mencapai 88.1 juta orang dan 79 juta di antaranya merupakan pengguna media sosial yang aktif, Media sosial sangat berperan dalam penyebaran informasi bagi masyarakat luas di semua bidang. Dalam penulisan ini, membahas penyebaran informasi di beberapa bidang saja seperti bidang bisnis, bidang pariwisata, bidang pendidikan, bidang keagamaan, kesehatan dan politik. Media sosial bisa dijadikan sebagai media promosi online di bidang bisnis dimana orang-orang dapat mengunjungi tautan yang berisi informasi mengenai produk dan lain-lain, Sosial media adalah platform yang mampu memfasilitasi berbagai kegiatan seperti mengintegrasikan situs web, intraksi sosial, dan pembuatan konten berbasis komunikasi. Melalui layanan sosial media dapat memfasilitasi konten, komunikasi dan percakapan. Pemakaian dapat membuat/concreate, mengatur, mengedit, mengomentari, mentag, 
mendiskusikan, menggabungkan, mengkoneksikan dan berbagi konten. (Indika and Jovita 2017)(Fitriani 2017)-(Tresnawati 2018).

4. Strategi promosi di era digital dengan canel youtube

Pada awalnya Youtube memang dirancang sebagai sosial media, namun seiring perkembangannya Youtube telah menjadi alat pemasaran yang menjanjikan, sebagai bentuk pemasaran YouTube menawarkan kesempatan bagi para pengunjung untuk mencari kegiatan khusus, menonton ulasan, mencari bantuan dan nasihat atau masukan tentang tujuan mereka. YouTube juga merupakan alat pemasaran yang berguna, karena memungkinkan pemilik perusahaan untuk membuat video promosi, Media digital memicu munculnya variasi bentuk presentasi diri. Video blogging (vlogging), merupakan salah satu bentuk presentasi diri yang kianpopuler. Hal ini didukung oleh kemunculan beragam media sosial yang mengutamakan konten video. Vlogging di era digital dianggap sebagai bentuk inovasi entrepreneurship baru. Para pelaku vlogging disebut vlogger (video blogger). Banyak orang menjadi vlogger profesional dan meraup keuntungan material dan nonmaterial dari ketenaran mereka, Sosial media yang hampir semua orang memunyai akun tersebut terkadang masih lepas dari segmen pengusaha ekonomi kreatif, padahal jika kita cermati hampir setiap saat dan tempat semua orang sudah tidak asing lagi dengan sosial media mulai dari facebook, twitter, instagram, maupun sosial media lainnya, namun kenyataanya masih banyak pengusaha yang kurang fokus terhadap keadaan tersebut. Hal ini harus menjadi sasaran tersendiri bagi pengusaha akibat dari ekonomi digital itu sendiri, sebab dengan bersosial media maka pengusaha juga mempunyai keuntungan tersendiri yang diantaranya selain biaya lebih rendah juga dapat lebih dekat dengan pelanggan sehingga tahu kekurangan serta kelebihan produk atau jasa yang kita miliki, hal ini sebagai fedback dan perbaikan dikemudian hari, YouTube merupakan social media yang sekarang-sekarang ini orang banyak menggunakannya, YouTube menyediakan berbagai macam video dari video clip, film, drama, animasi, berita, informasi apapun serta video yang dibuat oleh pengguna YouTube itu sendiri atau sering didengar dengan sebutan YouTuber. YouTube di era ini juga bisa mempromosikan perusahaan atau profil individu, dengan adanya YouTube seseorang dituntut untuk lebih kreatif membuat video yang menarik untuk mempromosikan dirinya sendiri. (Dhanar Intan Surya Saputra, Sitaresmi Wahyu Handani 2017)(Mahameruaji et al. 2018)-(Sholihin, Arianto, and Khasanah 2018)-(Ellida, Hikmah, and Yulianti 2020).

\section{METODE KEGIATAN}

Pelaksanaan pengabdian program pengabdian masyarakat ini dilakukan dengan melakukan solusi yang dirancang pada solusi permasalahan dengan menggunakan kompetensi dari para anggota di bidangnya dan dibantu tim pelaksana pengabdian ini. Sasaran dari kegiatan ini adalah Sekolah Dasar Muhammadiyah 1 Unggulan di Keluarahan Kebun Ros Kecamatan Teluk Segara Kota.Detail dari metode pelaksanaan dapat diperlihatkan pada Tabel 1 . Pelaksanaan ini dilakukan dengan dikelola oleh ketua anggota dan tim pelaksana pengabdian ini yang memiliki keahlian sesuai dengan bidang kegiatan yang akan dilakukan. 


\section{HASIL DAN PEMBAHASAN Tampilan Website Sekolah}

Pada halaman utama bagian atas menggunakan fasilitas carousel (bagian dari teknologi html) dengan tiga kegiatan yang ditampilkan. Bagian ini menampilkan slide show tiga kegiatan sekolah yang dipilih. Pada halaman

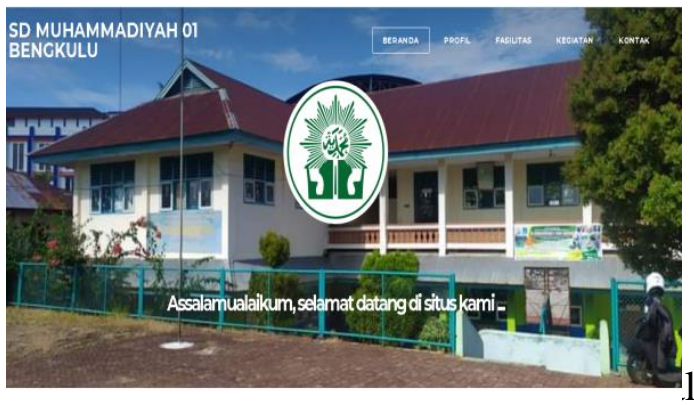
SD MUHAMMADIYAH 01
BENGKULU

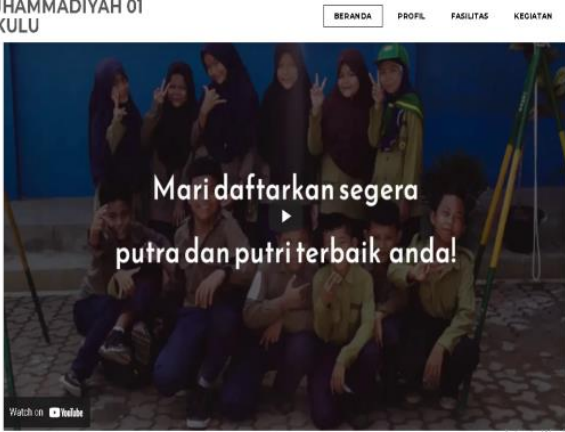

selanjutnya kata sambutan dari Kepala Sekolah Sekolah Dasar MUhammadiyah I Unggulan Kota Bengkulu, ucapan selamat datang kepada peserta dan pemateri yang berasedia hadir pada acara Pengabdian Kepada Masyarakat ini serta sedikit wejangan kepada peserta untuk mengikuti rangkaian acara dan berharap ada manfaat dari kegiatan ini, pentingnya sistem informasi dalam bentuk website sebagai sarana peningkatan pembelajaran dan promosi sekolah di era digital yang semakin maju dimana penggunaan smartphone begitu masif oleh kalangan generasi muda dalam mempermudah pekerjaan mereka serta keadaan sekolah dimana belum tersedia website yang memungkinkan bagi pihak sekolah untuk menginformasikan kegiatan-kegiatan yang dilakukan yang utama memiliki empat tombol navigator yang berada di bagian atas halaman web, dengan masing - masing nama navigasinya terdiri dari Berand, Profil, Fasilitas, Kegiatan dan Kontak.

berhubungan dengan pengajaran dan ekstrakulikuler sebagai media promosi.

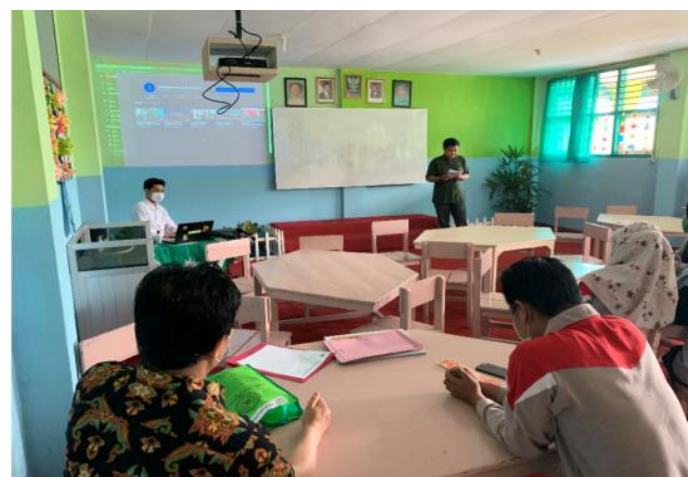

Gambar 3. Pembukaan Oleh MC

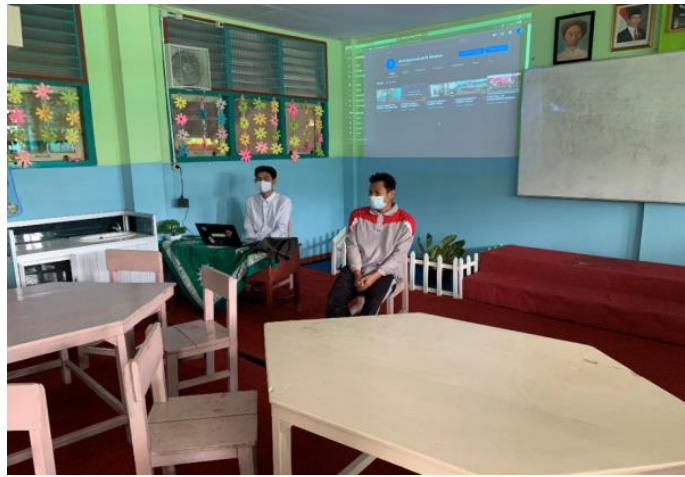

Untuk selanjutnya, materi oleh Pemateri 1 materi yang dipaparkan tentang Sosialisai tentang Kegiatan pengabdian kepada masyarakat ini maksud dan tujuan diadakan pelatihan/tutorial ini dan perkembangan komputer secara umum dan pentingnya teknologi informasi bagai setiap sektor khusunya sektor pendidikan dan pemaparan materi secara garis besar dan pentingnya internet sebagai media pembelajaran dan promosi sekolah, Menentukan ide website, register nama domain, pilih web hosting, cara membuat website dan pilihan platform, 
buat rencana untuk mengembangkan website, bisa di akses di bit.ly/sdm01bkl.

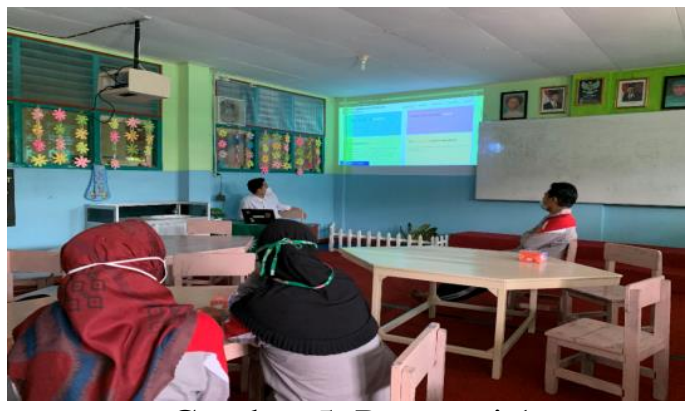

Gambar 5. Pamateri 1

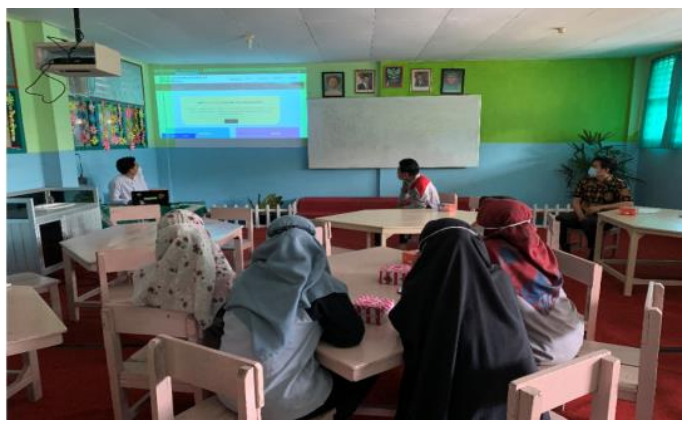

Gambar 6. Suasana Pelatihan

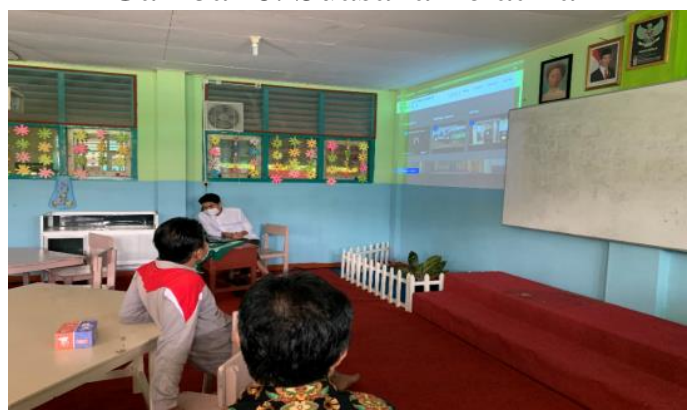

Gambar 5. Tentang penggunaan Medsos

Pemateri kedua tentang, Peningkatan Mutu Pembelajaran dengan Media digital Peningkatan Mutu Pembelajaran dengan Media digital yang berhubungan dengan Blended learning, distant learning (Pendidikan jarak Jauh), mobile learning (M-learning), Virtual Learning enviroment, Materi berikutnya Promosi lewat Medsos tentang Pemahaman tentang jenis Sosmed yang tepat, reponting konten blog, gunakan hastags, sebarkan konten di twitter, sebarkan konten di google dan sebarkan konten di linkedln.

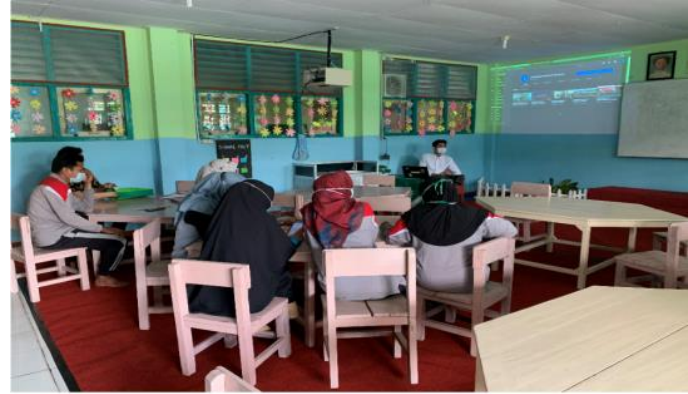

Gambar 7. Penggunaan Linked

Pemateri tiga tentang Strategi promosi di era digital dengan canel youtube yang berhubungan dengan Kompetitor di YouTube, Channel YouTube harus Fokus yang Jelas, Menentukan Genre Video, Video YouTube kita Memiliki Kualitas, ada Kalimat Ajakan di dalam Deskripsi Video, terjadwal, uptodate.

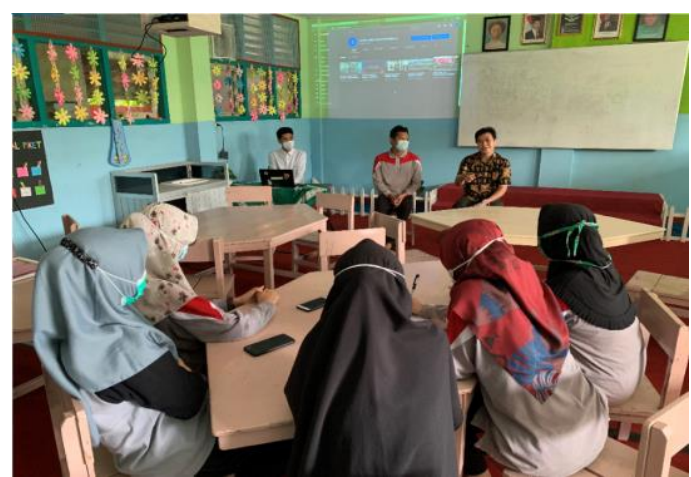

Gambar 8. Pamateri 3 tentang penggunaan Chanel youtube

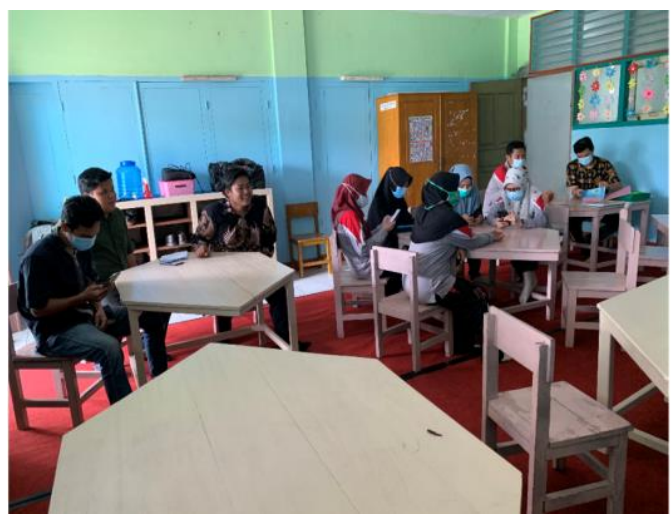

Gambar 9. Diskusi Kelompok

Adapun dokumentasi tentang pengenalan websiste sebagai media pembelajaran dan promosi Sekolah Dasar Muhammadiyah I Unggulan Kota 
Bengkulu dapat dilihat pada gambar berikut :

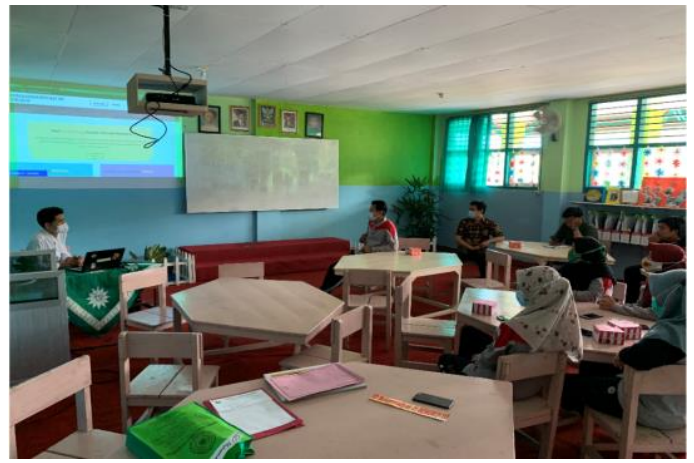

Gambar 10. Focus Ke Materi

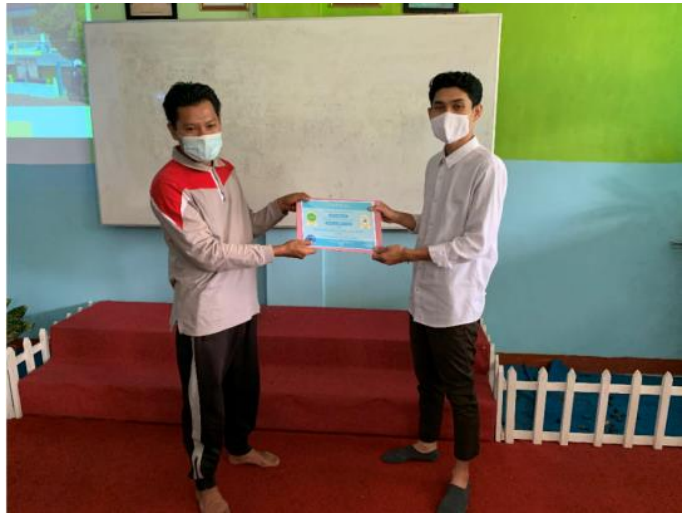

Gambar 11. Sera Terima Sertifikat Web

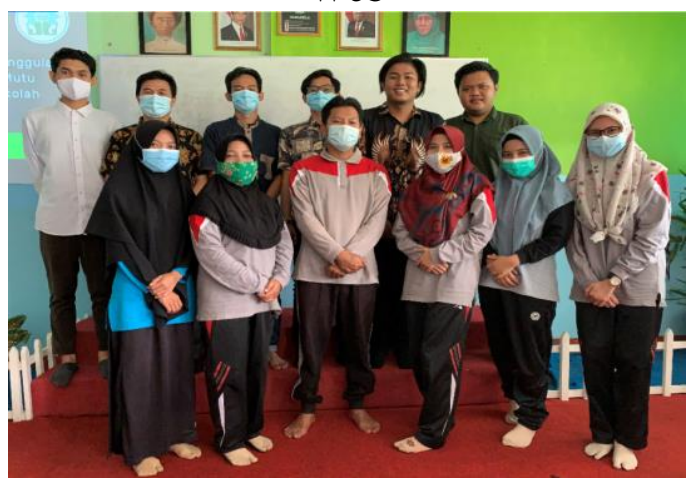

Gambar 12. Photo Bersama

Pada pengabdian ini, hasil yang didapat bukan hanya mitra memiliki pengetahuan sedikit banyak tentang internet, tahu cara melakukan laporan secara daring, bisa mecari sendiri bahanbahan ajar yang tersedia di situs yang kredibel baik beruapa teks, video ataupun aplikasi bahan ajar lengkap dan perluasan jaringan internet yang bisa menjangkau semua bagian.

\section{Pembahasaan}

Partisipasi Mitra
Mitra berpartisifasi penuh dengan menyediakan waktu, tenaga, pikiran serta menyiapkan sarana prasarana, guru, staf, ruang kelas dan fasilitasnya, serta sarana prasarana di sekolah mitra yang terkait dengan kegiatan dalam rangkah suksesnya kegiatan Pengabdian Kepada Masyarakat ini dan antusias peserta untuk mengkuti dengan sungguh dimana hampir setiap hari pesertanya hadir dan berpartisipasi dengan mengajukan pertanyaan-pertanyaan dan memintah pemateri untuk menjelaskan lebih lanjut dari materi yang ada.

Evaluasi program pelaksanaan program dilakukan dengan maksud untuk mengetahui sampai dimana tingkat ketercapaian program yang telah dilakukan dan ingin mengetahui letak kekurangan dan penyebabnya. Dalam kegiatan PKM ini dilakukan evaluasi terhadap kegiatan PKM ini adalah dengan cara evaluasi jangka pendek dengan menyebarkan kuisoner kepada guru/staf, Siswa dan orang ummum dan evaluasi jangka penjang dengan melakukan pemantahuan dlam jangka waktu tertentu diantaranya:

\section{PENUTUP}

Berdasarkan dari sosialisasi Berdasarkan dari sosialisasi yang telah diselenggarakan maka dapat pengabdian disimpulkan bahwa:

1. Kondosi Covid 19 menyebabkan banyak hambatan dalam pelaksanaan PKM ini karena banyaknya aturan yang harus diikuti mulai dari penggunaan masker, jaga jarak dan pembatasan peserta dalam ruangan.

2. Penggunaan aplikasi website ini diharapkan dapat dipergunakan untuk sarana pengingkatan mutu pembelajaran di mana informasi dan strategi pembelanjaran dapat di update setiap waktunya dan guru serta mahasiswa bisa mengakses data ini. 
3. Dari hasil Kuisoner yang diberikan untuk penggunaan media website yang terhubung dengan sosial media seperti Face Book, Twitter, Istagram dan Telegram dengan rank $81 \%$ $90 \%$ sebagai sarana promosi kegiatan dan prestasi guru/staf, siswa dan masyarakat umum.

4. Perlunya peningakatan sumber daya manusia yang ada di siswa Sekolah Dasar Muhammadiyah 1 Unggulan dengan mengadakan pelatihanpelatihan bidang IT dan Pengajaran daring.

\section{DAFTAR PUSTAKA}

Bibliography

(Budi Sutedjo, Dharma Oetomo dan Ester Wibow. 2007. "Pembuatan Website Portal Berita." Indonesian Journal on Networking and Security 3(3):1-14.

Abas, Wahiddin. 2013. "Analisa Kepuasan Mahasiswa Terhadap Website Universitas Negeri Yogyakarta (Uny)." Manajemen 16.

Arianti, Gusmia. 2017. "Kepuasan Remaja Terhadap Penggunaan Media Sosial Instragram Dan Path." WACANA, Jurnal Ilmiah Ilmu Komunikasi 16(2):180. doi: 10.32509/wacana.v16i2.21.

Azis, Taufiq Nur. 2019. "Strategi Pembelajaran Era Digital." Annual Conference on Islamic Education and Social Sains (ACIEDSS 2019) 1(2):308-18.

Dhanar Intan Surya Saputra, Sitaresmi Wahyu Handani, Feisal Rosdiana. 2017. "Membangun Channel Live Streaming YouTube Sebagai Alternatif Media Promosi Perguruan Tinggi." STMIK Amikom Purwokerto 116-20.

Ekayani, Putu. (2017). 2017. "Pentingnya Penggunaan Media."
(March).

Ellida, Rifa, Durotull Hikmah, and Diana Trivena Yulianti. 2020. "Implementasi Digital Marketing Pada Channel YouTube AGRO-TV Indonesia." 2(November):456-65.

Fitriani, Yuni. 2017. "Analisis Pemanfaatan Berbagai Media Sosial Sebagai Sarana Penyebaran Informasi Bagi Masyarakat." Paradigma - Jurnal Komputer Dan Informatika 19(2):148-52.

Haekal, Azwar, and Bambang Widjajanta. 2016. "Pengaruh Kepercayaan Dan Persepsi Risiko Terhadap Minat Membeli Secara Online Pada Pengunjung Website Classifieds Di Inonesia." Journal of Business Management Education (JBME) 1(1):183-95. doi: 10.17509/jbme.v1i1.2287.

Indika, Deru R., and Cindy Jovita. 2017. "Media Sosial Instagram Sebagai Sarana Promosi Untuk Meningkatkan Minat Beli Konsumen." Jurnal Bisnis Terapan 1(01):25. doi: 10.24123/jbt.v1i01.296.

Jayawardana, H. B. A. 2017. "Paradigma Pembelajaran Biologi Di Era Digital." Jurnal Bioedukatika 5(1):12. doi: 10.26555/bioedukatika.v5i1.5628.

Kaiful, Umam. 2013. "Penerapan Media Digital Dalam Pembelajaran Apresiasi Batik Kelas x SMA Negeri 1 Blega." Jurnal Pendidikan Seni Rupa 1(1):100-105.

Mahameruaji, Jimi Narotama, Lilis Puspitasari, Evi Rosfiantika, and Detta Rahmawan. 2018. "Bisnis Vlogging Dalam Industri Media Digital Di Indonesia." Jurnal ILMU KOMUNIKASI 15(1):61-74. doi: 10.24002/jik.v15i1.1007.

Meyliana. 2014. "PEMBUATAN SISTEM INFORMASI PENJUALAN BERBASIS WEB UNTUK MEMPERLUAS 
PANGSA PASAR Sandy.”

Pembuatan Sistem Informasi

Penjualan Berbasis Web Untuk

Memperluas Pangsapasar 225-32.

Putri, Aprilia Riyana, and Muhammad Alie Muzakki. 2019. "Implemetasi

Kahoot Sebagai Media

Pembelajaran Berbasis Digital

Game Based Learning Dalam

Mengahadapi Era Revolusi Industri

4.0." Prosiding Seminar Nasional

Universitas Muria Kudus 1-7.

Ratnamulyani, Ike Atikah, and Beddy

Iriawan Maksudi. 2018. "Peran

Media Sosial Dalam Peningkatan

Partisipasi Pemilih Pemula

Dikalangan Pelajar Di Kabupaten

Bogor." Sosiohumaniora

20(2):154-61. doi:

10.24198/sosiohumaniora.v20i2.13

965.

Setiawati, Mila. 2015. "Pengaruh Media

Sosial Terhadap Minat Beli

Konsumen." Sistem Informasi Akuntansi 13.

Sholihin, M. R., W. Arianto, and D. F.

Khasanah. 2018. "Keunggulan

Sosial Media Dalam Perkembangan

Ekonomi Kreatif Era Digital Di Indonesia." Prosiding 4th Seminar Nasional Dan Call for Papers 4758.

Tafonao, Talizaro. 2018. "Peranan

Media Pembelajaran Dalam

Meningkatkan Minat Belajar

Mahasiswa." Jurnal Komunikasi
Pendidikan 2(2):103. doi: 10.32585/jkp.v2i2.113.

Toyib, Rozali, Yulia Darnita, Analisi Situasi, Kabuapten Bengkulu, Utara Provinsi, and Provinsi Bengkulu. 2020. "Menggunakan Website Serta Pembukuan Sederhana." 3(1):27582.

Tresnawati, Y. 2018. "Pemanfaatan Media Sosial Dalam Promosi Potensi Wisata Bahari Cilacap Jawa Tengah." Perspektif Komunikasi: Jurnal Ilmu Komunikasi Politik ... 1(2).

Utama, Yadi. 2011. "Sistem Informasi Berbasis Web Jaringan Sistem Informatika Fakultas Ilmu Komputer Universitas Sruwijaya." Jurnal Sistem Informasi 3(2).

Wahidin, Unang. 2018. "Jurnal Edukasi Islami Jurnal Pendidikan Islam Implementasi Literasi Media ... Implementasi Literasi Media ...." Implementasi Literasi Media Dalam Proses Pembelajaran Pendidikan Agama Islam Dan Budi Pekerti 229-44.

Wardani, Susy Kusuma. 2013. "Sistem Informasi Pengolahan Data Nilai Siswa Berbasis Web Pada Sekolah Menengah Atas (Sma) Muhammadiyah Pacitan." Indonesian Jurnal on Networking and Security 2(2):2302-5700. 